\title{
THE INDEX EFFECT ON THE POLISH EQUITY MARKET BASED ON THE EXAMPLE OF THE WIG20 INDEX
}

\begin{abstract}
The aim of this article is to examine, on the example of companies whose shares are to be included into the WIG20 index portfolio, whether the index effect occurs on the Polish stock market. Based on the study event conducted in 2010-2014 (first quarter) it was demonstrated that abnormal positive returns of new index participants occurred mainly before the announcement of the information about the new index composition. Cumulative abnormal returns were observed for 9 out of 11 analysed companies and the average cumulative abnormal return amounted to $3.38 \%$. This means that on the Polish stock market, like on the foreign markets examined earlier, there is an anomaly in the form of the index effect.
\end{abstract}

Key words: index effect, event study, WIG20 index.

\section{INTRODUCTION}

Investment decisions made by professional market participants may contribute to the occurrence of anomalies on capital markets. The main reason behind this phenomenon is the herd instinct behaviour of asset managers (e.g. investment funds managers). This can be a sham herd instinct behaviour, i.e. actions independent of each other, taken, for example, on the basis of the same information, rationally processed. Such actions include, inter alia, investing in the shares of companies that are to be included in the index portfolio. This usually results in abnormal positive returns for new index constituents observed at the time of the announcement of a new composition of the index. This phenomenon is one of the most important manifestations of the, so called, index effect and has been confirmed by numerous studies, not only of the U.S. stock market, but also selected international stock markets. The hypothesis of the index effect (to the author's knowledge) has been relatively rarely verified on the Polish capital market ${ }^{1}$.

${ }^{*}$ Ph.D. hab., University of Lodz, Faculty of Economics and Sociology, Department of International Economics.

${ }^{1}$ Examples of analyses of the price behaviour of stocks included in and removed from the WIG20 index portfolio are studies carried out by Wiśniewski (for the period of 1998-2001) [Wiśniewski 2002: 62-64], Gurgul (for the period of 1995-2005) [Gurgul 2012: 155-170] and Hońdo (for the period of 2005-2010) [Hońdo 2010]. 
The aim of this paper is to undertake a preliminary analysis of the index effect on the Polish equity market, based on the example of the WIG20 index - the most important index published by the Warsaw Stock Exchange (WSE) and most frequently licensed by financial institutions, the one which comprises large-cap companies. The analysis covers the period of 2010-2014 (first quarter). The study concerns solely inclusions of shares in the aforementioned index (it passes over analysis of the situation when stocks were leaving the WIG20 index) and focuses only on the observation of stock prices (it does not take into account volume changes) in the period before and after the announcement date of modifications in the index portfolio. Due to the negligible role of index funds and passively managed exchange-traded funds using physical replication mirroring the results of the Polish blue-chips index, analysis of the index effect at the time of the actual change in the composition of the WIG20 index was abandoned in this study.

\section{REVIEW OF PREVIOUS RESEARCH}

Index effect research carried out so far has usually comprised analysis (based on the event studies method) of the occurrence of abnormal positive returns observed at the time of announcing the information about the inclusion of certain stocks in the index portfolio ${ }^{2}$; many authors also analysed in their studies changes in stock prices after publication of the information about their deletion from the index composition. In practice, the studies generally consisted of verifying the price pressure hypothesis, which states that the change in demand is purely temporary and short-lasting while the fund managers adjust their investment portfolios to a new situation; it is usually the time between the announcement of the news about the planned index portfolio change and the date on which it actually occurs. Following the announcement of an index addition (index deletion), prices should be expected to rise (fall) in the interim period in order to compensate investors and market makers for the provision of the immediacy to fund managers. However, since temporary changes in demand do not alter the equilibrium price of shares in the long term, the price changes are not persistent - in effect they return to their original levels when the activity of fund managers decreases [Pullen and Gannon 2007: 4].

Studies of the index effect have been conducted since the mid-1980s. Initially, they focused on the U.S. market - in that case, the index effect was tested mostly on the example of the S\&P 500 index; in subsequent years research on the S\&P 400 index and S\&P 600 index, to name just a few, was

${ }^{2}$ Event study methodology has been used in the research of various kinds of events on financial markets since the 1930s. The result of the first study of this kind was probably published by Dooley in 1933. The concept of such research was developed in the 1960s by Ball and Brown [1968], Fama [1969] and many others [MacKinlay 1997: 13-14]. 
published (the results of several selected studies are presented in Table 1). They confirmed the occurrence of statistically significant positive abnormal returns on the announcement date of the intended inclusion of the company in the index portfolio, though the scale of these abnormal returns varied.

In contrast to U.S. market research, the results of the studies relating to international markets are diverse as far as the scope of the index effect is concerned. Although, as illustrated in Table 2, abnormal returns on the Italian, British, German, New Zealand, Canadian, Turkish, Japanese, Danish and Australian markets were positive, the results of half of the aforementioned studies turned out to be statistically insignificant at any essential level.

Table 1. Results of selected studies of the index effect on the U.S. market in the case of announcing the information about the inclusion of stocks into the index portfolio

\begin{tabular}{|c|c|c|c|c|}
\hline $\begin{array}{c}\text { Date of study } \\
\text { publication }\end{array}$ & Authors of the study & $\begin{array}{c}\text { Abnormal } \\
\text { return (\%) }\end{array}$ & Study period & Index \\
\hline \hline 1986 & Harris and Gurel & $3.13^{*}$ & $1978-1983$ & S\&P 500 \\
\hline 1986 & Shleifer & $2.79^{*}$ & $1976-1983$ & S\&P 500 \\
\hline 1987 & Jain & $3.07^{*}$ & $1977-1983$ & S\&P 500 \\
\hline 1991 & Dhillon and Johnson & $3.33^{*}$ & $1984-1988$ & S\&P 500 \\
\hline 1996 & Beneish and Whaley & $4.39^{*}$ & $1986-1994$ & S\&P 500 \\
\hline 1997 & $\begin{array}{c}\text { Lynch } \\
\text { and Mendenhall }\end{array}$ & $3.16^{*}$ & $1990-1995$ & S\&P 500 \\
\hline 2002 & Breazeale and Cuny & $\begin{array}{l}6.74^{*} \\
9.00^{*}\end{array}$ & $2000-2001$ & $\begin{array}{c}\text { S\&P MidCap 400 } \\
\text { S\&P SmallCap 600 }\end{array}$ \\
\hline
\end{tabular}

Note: * statistically significant at $5 \%$ level.

Source: Pullen and Gannon [2007: 7].

Table 2. Results of studies of the index effect on selected international markets in the case of announcing the information about the inclusion of stocks into the index portfolio

\begin{tabular}{|c|c|c|c|c|}
\hline $\begin{array}{c}\text { Date of study } \\
\text { publication }\end{array}$ & Authors of the study & $\begin{array}{c}\text { Abnormal } \\
\text { return (\%) }\end{array}$ & Study period & Index \\
\hline \hline 2000 & $\begin{array}{c}\text { Barontini and } \\
\text { Rigamonti }\end{array}$ & 0.84 & $1995-1999$ & Mib 30 \\
\hline 2000 & Brealey & 0.50 & $1994-1999$ & FTSE \\
\hline 2000 & Deininger et al. & $1.72 *$ & $1988-1997$ & DAX \\
\hline 2000 & Li, Pinfold and Elayan & 0.91 & $1994-1998$ & NZSE 40 \\
\hline 2000 & Masse et al. & $1.58^{*}$ & $1989-1994$ & TSE 300 \\
\hline 2001 & Bildik and Gulay & 0.16 & $1995-2000$ & ISE 100 \\
\hline 2001 & Liu & $1.54 *$ & $1991-1999$ & Nikkei 500 \\
\hline 2002 & Bechman & 0.26 & $1989-2001$ & KFX \\
\hline $2002 * *$ & Chan and Howard & $2.60 *$ & $1992-1998$ & All Ordinaries \\
\hline
\end{tabular}

Note: * statistically significant at $5 \%$ level, ** abnormal returns relate to the implementation date of the index portfolio change.

Source: Pullen and Gannon [2007: 9]. 


\section{METHODOLOGY}

Two types of research were used to analyse the effect of announcing the information about the inclusion of shares in the WIG20 index on the Warsaw Stock Exchange. The first study compared fluctuations of the analysed stock prices with the WIG20 index, while the second one consisted of calculating the cumulative abnormal returns of these companies based on the market model (the methods will be discussed more thoroughly later in this article). The second research was conducted in accordance with the method appropriate for event studies when market reaction to specific events is analysed. As part of the research, a group of companies involved in the event under study was selected (i.e. firms whose shares were included in the index portfolio). Next, the moment when the information about this event was announced to the public was determined. Afterwards, the prices of these shares were examined over the, so-called, estimation period and finally and quotations of the shares were analysed over the, so-called, observation period, i.e. immediately before and after the information appeared.

The observation period (observation window, event window) $\left(t_{o b s}\right)$ adopted in the study covers 21 days $^{3}$ : the time from the tenth day before the event date $\left(t_{\text {pre }}\right)$ until the day preceding the event $[-10,-1]$, event date [0] and the period from the day following the event date until the tenth day after the event date $\left(t_{\text {post }}\right)[1,10]$. Relatively short, 21-day, periods of analysis allow better verification of (than in the case of a longer period) the impact of the analysed event on the prices of the shares included in the index portfolio. The period in question is used in a significant number of event studies [Peterson 1989: 36-66; Kiete and Uloza 2005: 12-13); moreover, a 10-day period prior to the event date is close to the period between the date of the index ranking on the Warsaw Stock Exchange $^{4}$ (i.e. the date when the ranking of companies is created, on the basis of which decisions modifying index portfolios - the WIG20 index including - are made) and the event date.

The event date is the day following the WSE announcement of the information about revision or adjustment of the index portfolio, as - similarly to other stock exchange markets (including, for example, stock exchange markets in the U.S.) - this information is made public only after the completion of stock

\footnotetext{
${ }^{3}$ In this and subsequent cases the period refers to trading (session) days.

${ }^{4}$ The rules for creating the index ranking on the Warsaw Stock Exchange (including, inter alia, the WIG20 index) are defined in ,specific rules of construction and publication of exchange indices and sub-indices" (appendix to Resolution No. 42/2007 of the WSE Management Board dated 16 January 2007 (as amended)) - Chapter II, Section 1. The index ranking is created after the last trading session in January, April, July and October (ranking date).
} 
exchange quotations ${ }^{5}$. Estimation period $\left(t_{\text {est }}\right)$ includes a 100-day period (from $110^{\text {th }}$ day before the event date to the $11^{\text {th }}$ day before the event date) and directly precedes the observation period. Although it is shorter than the one typically used in similar studies (according to Kothari and Warner, the estimation period in event studies is usually 190 days) [Kothari and Warner 2007: 3-36], it seems to be long enough (about four months) to eliminate any potential impact of seasonal effects on stock prices. In addition, an excessive estimation period can make the assumption of the immutability of the parameters adopted in a market model far from reality [Szyszka 2002: 80-88].

Illustration of the test period is shown in Figure 1.

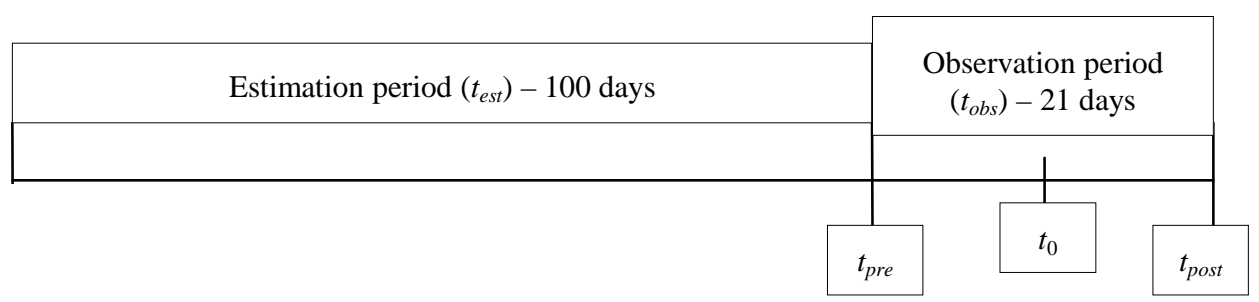

Figure 1. Estimation period and observation period in the study

Source: own study.

The first study involves comparison of the market prices of company shares from the sample with WIG20 index quotations on each day of the observation period, as well as comparing the average cumulative return of shares of the analysed companies with a cumulative return of the index during the entire observation period. For this purpose, the share price of each single company and quotations of the WIG20 index were analysed for 21 days $[-10,10]$, taking as a reference point the first day of the observation period $\left(t_{p r e}\right)$ (for comparison purposes, it was assumed that the price of shares and the value of the WIG20 index was 100 points on this particular day). The study ends on the last day of the observation period, i.e. the tenth day after the publication of the information about the change in the composition of the index portfolio $\left(t_{p o s t}\right)$. The average cumulative return of shares in the entire observation period is calculated using the following formula:

$$
A \nu C R_{t_{\text {pre }}-t_{\text {post }}}=\frac{\sum_{i=1}^{n} R_{i, t_{\text {pre }}-t_{\text {post }}}}{n}
$$

${ }^{5}$ An exception to this rule is, inter alia, Australian Securities Exchange (ASX) where Standard \& Poor's announces the information about planned changes in the composition of indices before the stock exchange session opens [Pullen and Gannon 2007: 14]. 
wherein:

$$
R_{i, t_{\text {pre }}-t_{\text {post }}}=\frac{P_{i, t_{\text {post }}}-P_{i, t_{\text {pre }}}}{P_{i, t_{\text {pre }}}} \times 100 \%
$$

where: $\begin{aligned} & A v C R_{t_{\text {pre }}-t_{\text {post }}}- \text { average cumulative return of } n \text { companies from the day } t_{\text {pre }} \\ & \text { to the day } t_{\text {post }},\end{aligned}$

$R_{i, t_{p r e}-t_{\text {post }}} \quad$ - return of $i$ company from the day $t_{\text {pre }}$ to the day $t_{\text {post }}$,

$P_{i, t_{\text {pre }}} \quad-$ closing price of $i$ company on the first day of observation $\left(t_{\text {pre }}\right)$, $\begin{array}{ll}P_{i, t_{\text {post }}} & - \text { closing price of } i \text { company on the last day of observation } \\ \left(t_{\text {post }}\right) .\end{array}$

In a similar way, the cumulative return of the index during the observation period is calculated.

In the second study, abnormal returns $(A R)$ of shares belonging to the sample relative to the index are calculated. According to MacKinlay, the abnormal return can be defined as ,actual ex post return of the security over the event window minus the normal return of the firm over the event window; the normal return is defined as the expected return without conditioning on the event taking place" (e.g. inclusion of shares into the index portfolio) [MacKinlay 1997: 15]. The procedure for calculating abnormal returns is carried out using a market model following the recommendations of Brown and Warner [Brown and Warner 1985: 3-31), Peterson [1989: 36-66] and others. This model is more useful than, for example, economic models (e.g. CAPM model, APT model or three-factor Fama -French model) in the case of event clustering, when at the same time the information about the planned inclusion of shares of more than one firm into the index portfolio appears. In accordance with that model, the return of the $i$ company shares is a result of the process that can be described with the equation:

$$
R_{i t}=\alpha_{i}+\beta_{i} R_{m t}+\varepsilon_{i t}
$$

where:

$R_{i t} \quad$ - return on a share of $i$ company in period $t$,

$\alpha_{i}, \beta_{i}$ - alpha and beta coefficients of $i$ company,

$R_{m t} \quad-$ return on index in period $t$,

$\varepsilon_{i t} \quad-$ uncorrelated residual element with the residual value of zero $\left(\mathrm{E}\left[\varepsilon_{i t}\right]=0\right)$. 
According to the above equation, the return on shares of $i$ company consists of a system component, linearly dependent on the return of the market portfolio (index), as well as a non-system component $\left(\varepsilon_{i t}\right)$ independent of the behaviour of the market as a whole. It is assumed that a specific event for the company (such as announcing inclusion of its shares into the index portfolio) is fully included in the latter of the above-mentioned components.

Returns on stocks and return on the index are calculated taking into account continuous capitalisation using the following formulas:

$$
\begin{aligned}
& R_{i t}=\ln \frac{P_{i t}}{P_{i t-1}} \\
& R_{m t}=\ln \frac{P_{m t}}{P_{m t-1}}
\end{aligned}
$$

where:

$P_{i t}, P_{m t} \quad-$ price (value) of $i$ company share (index) in period $t$, $P_{i t-1}, P_{m t-1}-$ price (value) of $i$ company share (index) in period $t-1$.

In turn, the $\hat{\alpha}_{i}$ and $\hat{\beta}_{i}$ parameters are evaluated over the estimation period (based on the observed relationship between returns on stock and returns of the market portfolio (index)) using the ordinary least squares (OLS) method. After determining these parameters and returns, the abnormal return for the company shares is calculated using the equation:

$$
A R_{i t}=R_{i t}-\left(\hat{\alpha}_{i}+\hat{\beta}_{i} R_{m t}\right)
$$

where:

$A R_{i t} \quad-$ abnormal return on the $i$ company in period $t$.

Thus, the abnormal return of the company during the observation period is the difference between the actual return on a given day and the normal return calculated on the basis of market model parameters specified after observing the behaviour of company share prices relative to the index in the preceding period (estimation period).

After calculating the abnormal return over a given time, the cumulative abnormal return $(C A R)$ for the whole observation period (i.e. from the tenth day prior to the event to the tenth day after the event) is determined using the formula: 


$$
C A R_{i, t_{\text {pre }}-t_{\text {post }}}=\sum_{t_{\text {pre }}}^{t_{\text {post }}} A R_{i t}
$$

where:

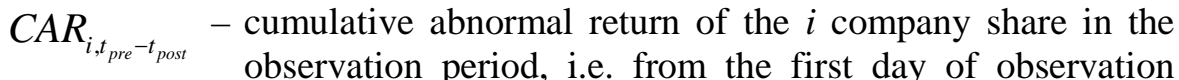
$\left(t_{\text {pre }}\right)$ to the last day of observation $\left(t_{\text {post }}\right)$.

After counting up cumulative abnormal returns for all the companies from the sample, the average cumulative abnormal return $(A C A R)$ is finally determined. It is equal to the arithmetic mean of the cumulative abnormal returns of $n$ company shares in the observation period:

$$
A C A R_{t_{\text {pre }}-t_{\text {post }}}=\frac{\sum_{i=1}^{n} C A R_{i, t_{\text {pre }}-t_{\text {post }}}}{n}
$$

where:

$$
\begin{aligned}
& \text { period, i.e. from the first day of observation }\left(t_{\text {pre }}\right) \text { to the last } \\
& \text { day of observation }\left(t_{\text {post }}\right) \text {. }
\end{aligned}
$$

\section{SAMPLE SELECTION AND MARKET DATA}

The study covered the period from $1^{\text {st }}$ January 2010 to $31^{\text {st }}$ March 2014. At that time, there were 5 annual revisions, 12 quarterly adjustments and 7 extraordinary adjustments of the WIG20 index portfolio in total; moreover, there were 3 other changes typically associated with the periodic deletion of shares of a given company from the WIG20 index calculation as a result of the completion of its quotation with pre-emptive rights. During 10 revisions and adjustments, the list of index participants changed - presentation of the most important modifications is displayed in Table 3 . In other cases, there was only a change in the number of shares of a particular company in the index portfolio (5 extraordinary adjustments), or there was no change in the index (nine times).

During 10 revisions and adjustments of the WIG20 index portfolio, altogether, shares of 13 companies were included in that portfolio. For two of them (PZU and JSW) either the estimation period could not be determined (an extraordinary adjustment as a result of which the shares of PZU were included in the WIG20 index, occurred two days after its IPO), or the estimation period was too short (JSW shares were included in the WIG20 index just 14 days after its 
IPO). Although in the case of two other companies the estimation period was also shorter than 100 days (also because of their recent IPO), it was still longer than the minimum period given in the study assumptions (50 days) - such a situation occurred in the case of PGE (56 days) and Tauron ( 84 days) - hence, these two companies were included in the sample. The subject of the study were, therefore, 11 companies (in chronological order): PGE, Tauron Polska Energia, Kernel, Bogdanka, Bank Handlowy, Boryszew, Synthos, Eurocash, BZ WBK, Alior Bank and LPP.

Table 3. Changes in the WIG20 index portfolio resulting in the inclusion and deletion of company shares in/from the portfolio covering the period of 1 January 2010-31 March 2014

\begin{tabular}{|c|c|c|c|c|c|r|}
\hline No. & $\begin{array}{c}\text { Nature of } \\
\text { change }\end{array}$ & $\begin{array}{c}\text { Announcement } \\
\text { date }\end{array}$ & $\begin{array}{c}\text { Date of } \\
\text { change }\end{array}$ & $\begin{array}{c}\text { Companies } \\
\text { removed from } \\
\text { the index }\end{array}$ & $\begin{array}{c}\text { Companies } \\
\text { included in } \\
\text { the index }\end{array}$ & $\begin{array}{c}\text { Number of } \\
\text { shares of } \\
\text { a new } \\
\text { company } \\
\text { in the index } \\
\text { (in thousands) }\end{array}$ \\
\hline \hline 1 & $\begin{array}{c}\text { annual } \\
\text { revision }\end{array}$ & 11.02 .2010 & 19.03 .2010 & Agora & PGE & 259514 \\
\hline 2 & $\begin{array}{c}\text { extraordinary } \\
\text { adjustment }\end{array}$ & 12.05 .2010 & 14.05 .2010 & Cersanit & PZU & 36106 \\
\hline 3 & $\begin{array}{c}\text { quarterly } \\
\text { adjustment }\end{array}$ & 09.11 .2010 & 17.12 .2010 & Bioton & $\begin{array}{c}\text { Tauron } \\
\text { Polska } \\
\text { Energia }\end{array}$ & 932734 \\
\hline 4 & $\begin{array}{c}\text { annual } \\
\text { revision }\end{array}$ & 10.02 .2011 & 18.03 .2011 & $\begin{array}{c}\text { Cyfrowy } \\
\text { Polsat } \\
\text { Kolimex } \\
\text { Kernel }\end{array}$ & $\begin{array}{c}\text { Bogdanka } \\
\text { Mostostal }\end{array}$ & 30771 \\
\hline 5 & $\begin{array}{c}\text { extraordinary } \\
\text { adjustment }\end{array}$ & 01.04 .2011 & 05.04 .2011 & BZ WBK & $\begin{array}{c}\text { Bank } \\
\text { Handlowy }\end{array}$ & 32665 \\
\hline 6 & $\begin{array}{c}\text { quarterly } \\
\text { adjustment }\end{array}$ & 08.08 .2011 & 16.09 .2011 & CEZ & JSW & 39496 \\
\hline 7 & $\begin{array}{c}\text { annual } \\
\text { revision }\end{array}$ & 09.02 .2012 & 16.03 .2012 & $\begin{array}{c}\text { Getin } \\
\text { PBG }\end{array}$ & $\begin{array}{c}\text { Boryszew } \\
\text { Synthos }\end{array}$ & $\begin{array}{r}991664 \\
496691\end{array}$ \\
\hline 8 & $\begin{array}{c}\text { annual } \\
\text { revision }\end{array}$ & 07.02 .2013 & 15.03 .2013 & TVN & Eurocash & 77369 \\
\hline 9 & $\begin{array}{c}\text { quarterly } \\
\text { adjustment }\end{array}$ & 13.05 .2013 & 21.06 .2013 & Boryszew & BZ WBK & 28064 \\
\hline 10 & $\begin{array}{c}\text { annual } \\
\text { revision }\end{array}$ & 10.02 .2014 & 21.03 .2014 & $\begin{array}{c}\text { GTC } \\
\text { Bank }\end{array}$ & $\begin{array}{c}\text { Handlowy } \\
\text { LPP }\end{array}$ & 41408 \\
\hline
\end{tabular}

Source: own study.

The research used two types of data: closing prices of the company shares and the WIG20 index closing value. In both cases the data covered the estimation period and observation period - a total of 121 sessions (exact data 
regarding the aforementioned periods for each company are presented in Table 4). The source of that data was Bossa.pl (the website of Bank Ochrony Środowiska DM).

Table 4. Selected information about the sample

\begin{tabular}{|c|c|c|c|c|c|}
\hline No. & Company & $\begin{array}{c}\text { Estimation period } \\
{[-110,-11]}\end{array}$ & $\begin{array}{c}\text { Announcement date } \\
\text { of inclusion of the } \\
\text { company in the } \\
\text { WIG20 index [-1] }\end{array}$ & $\begin{array}{c}\text { Event date } \\
\text { (day after the } \\
\text { announcement day) } \\
{[0]}\end{array}$ & $\begin{array}{c}\text { Observation } \\
\text { period } \\
{[-10,10]}\end{array}$ \\
\hline \hline 1 & PGE & $\begin{array}{c}06.11 .2009 \\
-28.01 .2010\end{array}$ & 11.02 .2010 & 12.02 .2010 & $\begin{array}{c}29.01 \\
-26.02 .2010\end{array}$ \\
\hline 2 & $\begin{array}{c}\text { Tauron } \\
\text { Polska } \\
\text { Energia }\end{array}$ & $\begin{array}{c}30.06 \\
-25.10 .2010\end{array}$ & 09.11 .2010 & 10.11 .2010 & $\begin{array}{c}26.10 \\
-25.11 .2010\end{array}$ \\
\hline 3 & Kernel & $\begin{array}{c}06.09 .2010 \\
-27.01 .2011\end{array}$ & 10.02 .2011 & 11.02 .2011 & $\begin{array}{c}28.01 \\
-25.02 .2011\end{array}$ \\
\hline 4 & Bogdanka & $\begin{array}{c}06.09 .2010 \\
-27.01 .2011\end{array}$ & 10.02 .2011 & 11.02 .2011 & $\begin{array}{c}28.01 \\
-25.02 .2011\end{array}$ \\
\hline 5 & $\begin{array}{c}\text { Bank } \\
\text { Handlowy }\end{array}$ & $\begin{array}{c}26.10 .2010 \\
-18.03 .2011\end{array}$ & 1.04 .2011 & 04.04 .2011 & $\begin{array}{c}21.03 \\
-18.04 .2011\end{array}$ \\
\hline 6 & Boryszew & $\begin{array}{c}05.09 .2011 \\
-26.01 .2012\end{array}$ & 09.02 .2012 & 10.02 .2012 & $\begin{array}{c}27.01 \\
-24.02 .2012\end{array}$ \\
\hline 7 & Synthos & $\begin{array}{c}05.09 .2011 \\
-26.01 .2012\end{array}$ & 09.02 .2012 & 10.02 .2012 & $\begin{array}{c}27.01 \\
-24.02 .2012\end{array}$ \\
\hline 8 & Eurocash & $\begin{array}{c}30.08 .2012 \\
-24.01 .2013\end{array}$ & 07.02 .2013 & 08.02 .2013 & $\begin{array}{c}25.01 \\
-22.02 .2013\end{array}$ \\
\hline 9 & BZ WBK & $\begin{array}{c}27.11 .2012 \\
-25.04 .2013\end{array}$ & 13.05 .2013 & 14.05 .2013 & $\begin{array}{c}26.04 \\
-28.05 .2013\end{array}$ \\
\hline 10 & Alior Bank & $\begin{array}{c}29.08 .2013 \\
-27.01 .2014\end{array}$ & 10.02 .2014 & 11.02 .2014 & $\begin{array}{c}28.01 \\
-25.02 .2014\end{array}$ \\
\hline 11 & LPP & $\begin{array}{c}29.08 .2013 \\
-27.01 .2014\end{array}$ & 10.02 .2014 & 11.02 .2014 & $\begin{array}{c}28.01 \\
-25.02 .2014\end{array}$ \\
\hline
\end{tabular}

Source: own study.

\section{RESULTS}

Comparison of the share prices of the analysed companies over their observation periods with the WIG20 index quotations over the same periods confirmed the conclusions of the research carried out on foreign markets. At the end of the entire 21-day observation period the average cumulative return of shares was $4.4 \%$, while the average cumulative return of the WIG20 index was $1.4 \%$ (Chart 1$)^{6}$. It is also worth noting that out of 11 companies, only in two of them (PGE and Kernel) was the difference between cumulative returns of shares

\footnotetext{
${ }^{6}$ Significantly bigger differences between these returns was recorded when using the median instead of the arithmetic mean - being $6.7 \mathrm{pp}$.
} 
and index negative, while for the other nine firms it was positive and, at the same time, was more than 8 percentage points in four cases (Eurocash $-10.3 \mathrm{pp}$, LPP - 10.0 pp, Boryszew - 9.5 pp, Bank Handlowy - 8.6 pp).

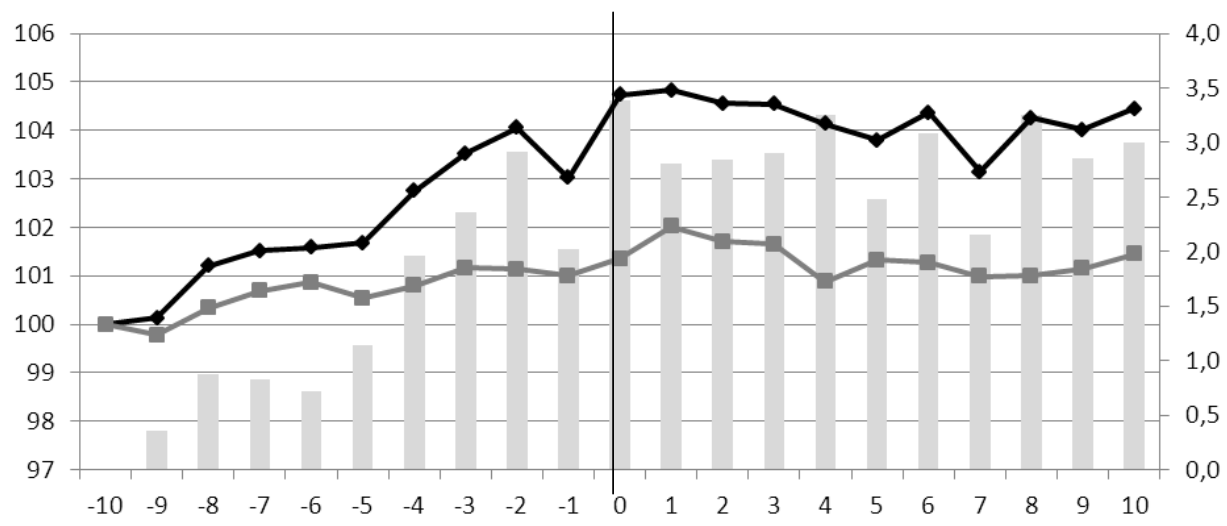

Difference between average cumulative return of shares and average cumulative return of WIG20 index (in pp) (right scale)

-Average cumulative return of shares (start of observation period $=100$ points) (left scale)

- - Average cumulative return of WIG20 index (start of observation period = 100 points) (left scale)

Chart 1 . The average cumulative return of shares from the sample and the average cumulative return of the WIG20 index during the observation period

Source: own study.

The difference between these returns increased significantly, especially in the period preceding the event day, i.e. the day following the announcement of the planned change in the index (this day is marked on Chart 1 as a vertical line), which is illustrated by the rising bar graph. On the event day, the difference reached its maximum level in the observation period (3.4 pp) and then, for the next 10 days, remained around this level oscillating between 2.2 and $3.3 \mathrm{pp}$. In the second part of the observation period, i.e. after the publication of information about the inclusion of company shares into the WIG20 index, fluctuations in both average cumulative returns were much smaller than in the period prior to the disclosure of this information. This means that the demand for shares from investors actively managing investment portfolio (who - in contrast to the entities applying passive management - react to the planned amendments in index portfolios before the actual change), resulting in a positive difference between cumulative returns of shares and the index in most cases, already appeared before the event day. This is a phenomenon resulting from, inter alia, a high transparency level of the indices, the methodology of which is based on 
clear, transparent principles (so-called rule-based indices) - such as the WIG20 index. Investors, especially institutional ones, knowing the rules according to which changes to the index portfolio are introduced (it is all about the knowledge of the principles behind the selection of companies for the index ${ }^{7}$ and about the dates when the information concerning potential changes in the portfolio is published) can, in fact, predict in advance not only when and which company will join the index constituents, or which firm will be removed, but also when the information on this topic will be announced. As for the WIG20 index, the information about annual revision or quarterly adjustment is made public at least five weeks prior to the actual change, hence professional investors are highly likely to determine, among other things, the date of its publication.

Table 5. Cumulative abnormal returns $(C A R)$ of shares of the companies included in the WIG20 index portfolio and the average cumulative abnormal return (ACAR) of these companies during the observation period of 2010-2014 (first quarter)

\begin{tabular}{|c|c|c|}
\hline No. & Company & CAR $(\%)$ \\
\hline \hline 1 & PGE & -8.93 \\
\hline 2 & Tauron Polska Energia & 1.23 \\
\hline 3 & Kernel & -5.56 \\
\hline 4 & Bogdanka & 3.02 \\
\hline 5 & Bank Handlowy & 7.94 \\
\hline 6 & Boryszew & 9.95 \\
\hline 7 & Synthos & 1.26 \\
\hline 8 & Eurocash & 6.80 \\
\hline 9 & BZ WBK & 6.01 \\
\hline 10 & Alior Bank & 7.13 \\
\hline 11 & LPP & 8.32 \\
\hline & $\boldsymbol{A C A R}(\boldsymbol{\%})$ & $\mathbf{3 . 3 8}$ \\
\hline
\end{tabular}

Source: own study.

The results of the study, the aim of which was to determine, on the basis of a market model, abnormal returns of company shares included in the WIG20 index portfolio from the beginning of 2010 to the end of the first quarter of 2014, appear similar to the results of the study discussed earlier. The average cumulative abnormal return $(A C A R)$ was $3.38 \%$, which means that the publication of information about the intended inclusion of shares of analysed companies into the index portfolio allowed for the obtaining of extraordinary

${ }^{7}$ In the WIG20 index this concerns primarily the rules according to which the index ranking is prepared every quarter. What also matters are the rules of extraordinary adjustments of the index. 
returns (especially in the period before the announcement of this information) ${ }^{8}$. Shares of two companies only - PGE and Kernel - experienced negative cumulative abnormal returns over the observation period, i.e. their actual returns were lower than the normal return. For other companies, the CAR indicator was positive, with four companies (Boryszew, LPP, Bank Handlowy and Alior Bank) exceeding $7 \%$ (Table 5).
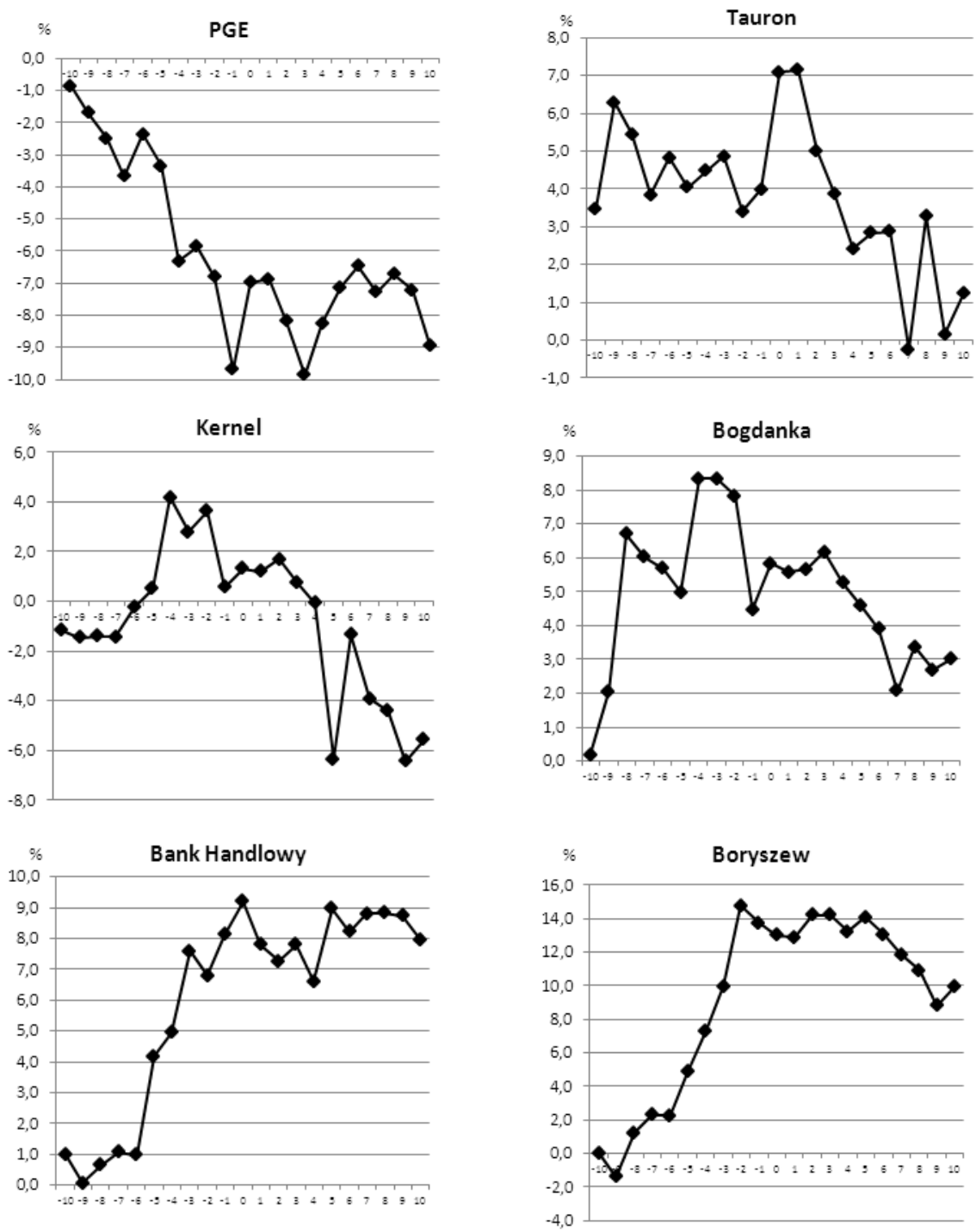

${ }^{8}$ As in the previous study, in this case the median of cumulative abnormal returns of 11 companies proved to be much higher than the arithmetic mean and amounted to $6.01 \%$. 

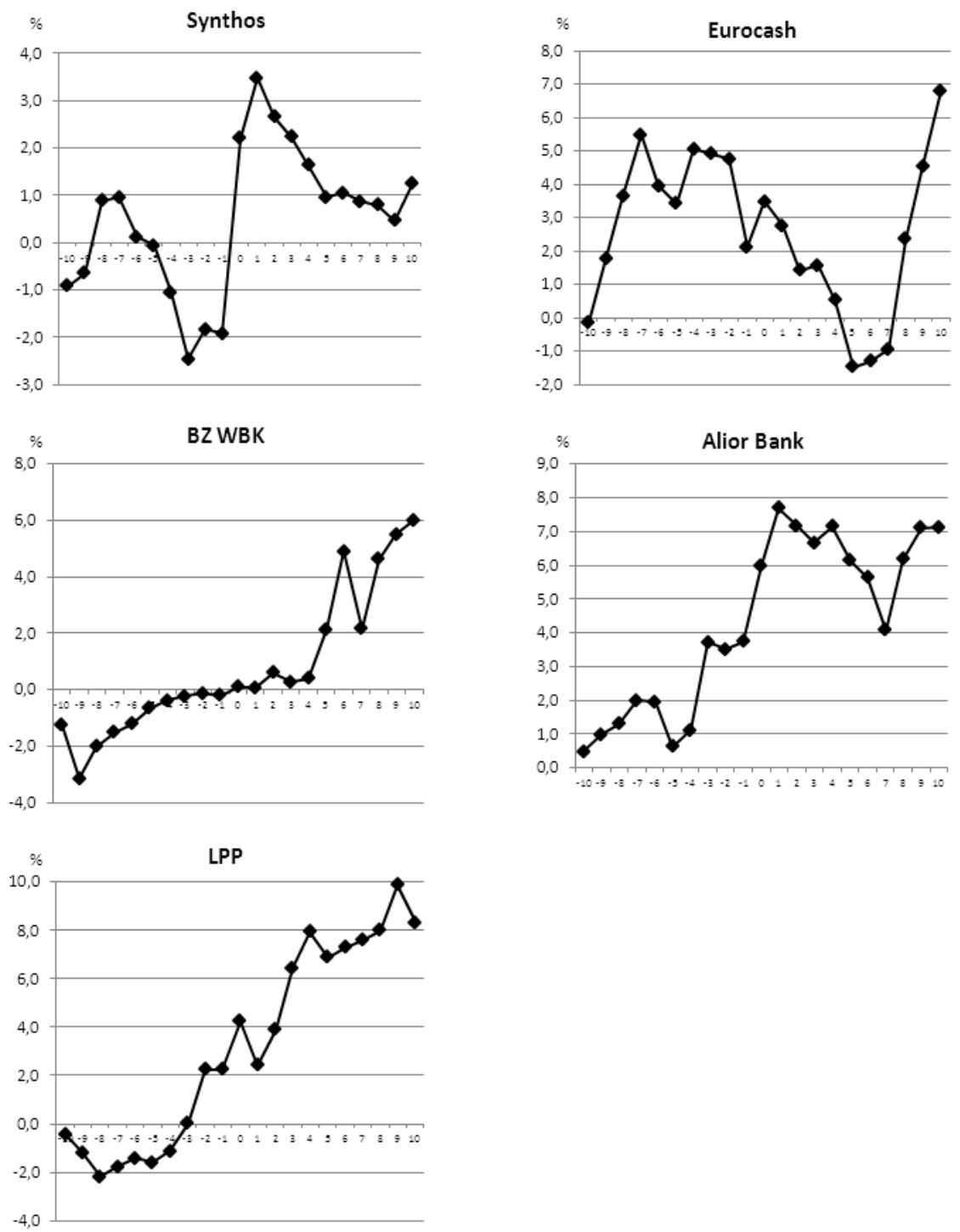

Chart 2. Cumulative abnormal returns $(C A R)$ of shares of the companies included in the WIG20 index portfolio during the observation period of 2010-2014 (first quarter)

Source: own study.

Similarly to the previous study, index effect (in the form of positive abnormal returns) also occurred in this case before the publication of the information about the change in the WIG20 composition. On the third day of the observation period (i.e. on the eighth day before the event day), the ACAR indicator already exceeded 
$1 \%$. Four days later it was higher than $2 \%$ and it reached its peak at a level above $4 \%(4.14 \%)$ on the day following the date of publishing by the WSE of the information about the planned modification of the index. On consecutive days, the ACAR indicator showed a slight downward trend (with minor upward adjustments) and at the end of the observation period reached 3.38\%.

\section{CONCLUSIONS}

The results of the conducted research showed that the index effect occurred in the instance of the inclusion of company shares into the WIG20 index portfolio on the Polish stock market in 2010-2014 (first quarter). During the observation period, covering 10 days before and 10 days after the event day, both the positive average cumulative abnormal returns on the shares of these companies and the positive difference between the average cumulative return of shares and the average cumulative return of the WIG20 index were recorded. Achieved results are, therefore, consistent with the results of similar studies carried out for at least three decades on foreign markets (especially in the U.S.). It should be emphasised that positive abnormal returns appeared before publishing the information about changes in the index portfolio, which may be explained by the anticipative reaction of investors (especially institutional ones). They are able - if the index is characterised by clear and commonly known methodology (and this includes the WIG20 index) - to predict not only the time of revision of the index or its adjustment, but also to determine which companies will be included in the index portfolio and which removed from it.

The study conducted in this article covered only one particular aspect of the index effect on the Polish stock market. In order to analyse this effect more comprehensively, it is however necessary to examine the occurrence of the above-mentioned effect at the moment of announcing the information about the deletion of shares from the index, as well as at the moment of actual changes in the index composition (both in relation to the addition (deletion) of companies into (from) the index). Moreover, as the research conducted so far on foreign markets indicates, the index effect is also often reflected by the increase in trading volume, which could also be studied with reference to the Polish stock market.

\section{REFERENCES}

Brown S. J., Warner J. B., 1985, Using Daily Stock Returns: The Case of Event Studies, Journal of Financial Economics 14, 3-31.

Gurgul H., 2012, Analiza zdarzeń na rynkach akcji. Wptyw informacji na ceny papierów wartościowych, $\left(2^{\text {nd }}\right.$ ed. $)$, Warszawa. 
Hońdo T., 2010, Wejście do WIG20 to powód do sprzedaży akcji?, Gazeta Giełdy Parkiet.

Kiete K., Uloza G., 2005, The Information Efficiency of the Stock Markets in Lithuania and Latvia, SSE Riga Working Papers.

Kothari S. P., Warner J. B., 2007, Econometrics of Event Studies, In: B. E. Eckbo (ed.), Handbook of Corporate Finance. Empirical Corporate Finance, vol. 1, Amsterdam.

MacKinlay A. C., 1997, Event Studies in Economics and Finance, Journal of Economic Literature $35,13-39$.

Peterson P. P., 1989, Event Studies: A Review of Issues and Methodology, Quarterly Journal of Business and Economics 28(3), 36-66.

Pullen D., Gannon G., 2007, The index effect: An investigation of the price, volume and trading effects surrounding changes to the $S \& P$ Australian indices, School Working Paper - Accounting/ Finance Series 2007, SWP 2007/07.

Szyszka A., 2002, Reakcje inwestorów, Nasz Rynek Kapitałowy 1(133), 62-64.

Wiśniewski T., 2002, Zmiany portfela WIG20, Nasz Rynek Kapitałowy 1(133), 80-88.

Tomasz Miziołek

\section{EFEKT INDEKSOWY NA POLSKIM RYNKU AKCJI NA PRZYKŁADZIE INDEKSU WIG20}

Celem artykułu jest zbadanie, na przykładzie spółek których akcje mają zostać włączone do portfela indeksu WIG20, czy na polskim rynku akcji występuje efekt indeksowy. Na podstawie studium wydarzeń przeprowadzonego w latach 2010-2014 (I kwartał) wykazano występowanie anormalnych dodatnich stóp zwrotu nowych uczestników indeksu pojawiających się przede wszystkim jeszcze przed ogłoszeniem informacji o nowym składzie indeksu. Skumulowane anormalne stopy zwrotu zanotowano w przypadku 9 spośród 11 przeanalizowanych spółek, zaś średnia skumulowana anormalna stopa zwrotu wyniosła 3,38\%. Oznacza to, że na polskim rynku akcji, podobnie jak na zbadanych wcześniej rynkach zagranicznych, występuje anomalia w postaci efektu indeksowego.

Słowa kluczowe: efekt indeksowy, studium wydarzeń, indeks WIG20. 